\title{
Mars 2018 - och sedan? Om successionsfrågan i Putins Ryssland
}

\author{
Bo Petersson * \\ Professor, Malmö universitet
}

\begin{abstract}
March 2018 - and then what? The issue of political succession in Putin's Russia As president of Russia and a prominent political leader, Vladimir Putin has consistently endeavored to legitimize his rule by appealing to central political myths and taken-for-granted truths in Russian society. In rhetoric and official communication, he emerges as the guarantor of domestic order and stability, the protector of traditional values, and a staunch advocate of Russia's status and position as a great power in a world often depicted as hostile. What is being communicated here, and apparently finds resonance among broad segments of public opinion, is that on all these parameters Putin is uniquely qualified to lead Russia. Four times in the course of 18 years, Putin has been elected president in the first round of elections, and throughout this period he has received high rankings in regular monthly opinion polls. However, his legitimation strategies have been so firmly linked to the persona of Putin that we may speak of an emerging dilemma with his fourth presidency. Who could fill his shoes as his successor? The article analyzes this dilemma, taking its point of departure in Weber's seminal theorizing on types of legitimate authority and the routinization of charisma. It discusses the evident dearth of credible successor candidates, and concludes by discussing possible actions for dealing with or postponing the issue of succession.
\end{abstract}

Keywords: Putin, legitimacy, charisma, routinization, succession

Den 18 mars 2018 valdes Vladimir Vladimirovitj Putin till president i Ryska Federationen för fjärde gången. Endast en valomgång behövdes för att kora honom som vinnare eftersom han med sina dryga $76 \%$ av rösterna fick långt över de enligt konstitutionen nödvändiga 50\% för att bli vald. I och med denna valseger kan han enligt grundlagens nuvarande regler sitta kvar som president fram till 2024. Då blir det 25 år sedan Putin först tog den ryska politiska scenen i besittning i samband med att president Boris Jeltsin utsåg honom till premiärminister år 1999.

Putin har konsekvent framställts som den utvalde, som den ende i dagens politiska liv som kan vara en garant för Rysslands nationella intressen. Han framhålls

^Kontaktinformasjon: Bo Petersson, e-post: bo.petersson@mau.se 
som en nationens räddare, en gestalt närmast bortom tid och rum (Snyder 2018). Putin tycks också själv dela uppfattningen att han skulle vara unikt kallad att uppbära presidentansvaret. Under sitt känsloladdade framträdande på Manegetorget i Moskva i samband med tillkännagivandet av segern vid förra presidentvalet, 2012, anklagade han sina motståndare för att falskeligen försöka tillskansa sig makten, för att usurpera den (Hutcheson \& Petersson 2016). Vilka dilemman aktualiseras då av Putins särställning i rysk politik? Hur kan en kommande efterträdares maktinnehav legitimeras och hur kan den samhälleliga stabiliteten bevaras? Hur har Putin själv kommenterat frågan och hur kan den komma att hanteras under hans fjärde mandatperiod som president? Det är dessa frågor som denna artikel ägnas.

\section{Successionsfrågan}

»Med undantag för de sällsynta sittande politiska ledare som frivilligt lämnar makten ifrån sig, agerar ledare övervägande utifrån att de vill hålla sig kvar vid makten så länge de kan", skriver statsvetarna Bruce Bueno de Mesquita och Alistair Smith (2017: 78). Efterträdarfrågan, eller snarare dess undvikande, står i centrum för alla beslut som politiska ledare tar, menar de. Ett tidigt identifierande av en efterträdare har onekligen sina risker. Det kan bli ett tveeggat svärd där efterträdaren kan bidra till att ge politiskt stöd åt sin mentor, men också kan rikta allvarliga utmaningar mot ledaren, för den händelse att stödet för denne skulle börja erodera (Konrad \& Mui 2016). Det var som bekant den förmente vännen Brutus som utdelade knivhugget mot Julius Caesar, inte någon av kejsarens i förväg kända motståndare och fiender.

Samtidigt kan inte riskerna med att peka ut en efterträdare fördölja nödvändigheten av att lösa hur efterträdarfrågan kan ske på ett reglerat sätt. Frågan är synnerligen central; det handlar om att identifiera själva den mekanism som garanterar att en stat överlever sin ledare (Kailitz \& Stockemer 2017; Snyder 2018). Ännu så länge har Vladimir Putin dock avstått från att peka ut någon kronprins.

I presidentvalet 2018 kunde i vart fall ingen tänkbar efterträdare skönjas bland dem som formellt ställde upp som Putins motkandidater. Kommunistpartiets kandidat Pavel Grudinin kom visserligen på andra plats med i sig aktningsvärda $11,8 \%$ av rösterna, men denna siffra reflekterade snarast kommunistpartiets traditionella röstetal i post-sovjetiska ryska presidentval. Startfältet i övrigt imponerade inte. Populisten Vladimir Zjirinovskij (5,65\%) och Griigorij Javlinskij från det liberala Jabloko $(1,05 \%)$ är båda gamla veteraner som ställde upp i presidentval redan i början av 1990-talet då Sovjetunionen just hade upplösts. Liberalen Ksenija Sobtjak, dotter till Putins gamle mentor, den bortgångne förre borgmästaren i S:t Petersburg Anatolij Sobtjak, lyckades med sin reformerade jetset-framtoning skrapa ihop 1,7\% av rösterna. De tre övriga kandidaterna, Sergej Baburin, Maksim Surajkin och Boris Titov, fick alla mindre än 1\% (Central Election Commission 2018). Det fanns ingen kronprins i denna skara. 
Vid några offentliga framträdanden inför valet fick Putin frågan hur han såg på efterträdarproblemet. Presidentens svar var undvikande och gick ut på att det var det ryska folkets sak att välja hans efterträdare när den dagen kom, så det lade han sig inte i (President of Russia 2016). I en intervju för den amerikanska TV-kanalen NBC upprepade han att detta var någonting som folket hade att besluta om, men att han hade funderat över efterträdarfrågan alltsedan han först tillträdde som president år 2000 (President of Russia, 2018b). Dock ville han inte ge någon antydan om hur han hade tänkt, utan sade bara kryptiskt att om man gjorde en internationell jämförelse skulle man konstatera att det fanns många ledande politiker runt om i världen som var äldre än han själv. Frågan brådskade alltså inte, tycktes han antyda.

År 2024 blir Putin 72 år om han får leva och ha hälsan. Den ryske presidenten har förvisso rätt $i$ att detta inte nödvändigtvis är någon särskilt hög ålder $i$ världspolitiken. Donald John Trump var 70 år när han valdes till USA:s president år 2016. I Malaysia vann den 92-årige Mahathir Mohamads parti parlamentsvalet i maj 2018 och han tillträdde som världens äldste premiärminister. Ändå är det oundvikligt att successionsfrågan aktualiseras i början av denna Putins fjärde mandatperiod, och "ett generationsskifte väntar obevekligt runt hörnet» (Bacon 2017: 2). Ett nytt arrangemang med ett valt statsöverhuvud som håller presidentfåtöljen varm åt Putin, likt Dmitrij Medvedev gjorde 2008-2012, är knappast troligt för åren 2024-2030 - då skulle Putin vara 78 vid sin återkomst, och det börjar ändå bli en tämligen hög ålder. Alltså måste successionsfrågan av allt att döma lösas under den 2018 påbörjade mandatperioden. Här utgör Putins särställning och utbredda popularitet ett problem om inte för honom själv så åtminstone för kretsen runt honom.

\section{Legitimitetsgrunder}

Max Webers klassiska indelning av tre legitima auktoritetstyper är fortfarande riktningsgivande i dagens litteratur om legitimitet (Weber 1983: 144-175; Netelenbos 2016). Legal auktoritet är den legitima auktoritetsform som företrädesvis finns i mogna, västerländska demokratier där ett troget iakttagande av landets konstitution och övriga lagar utgör basen för det förtroende som ledarna åtnjuter hos väljarna. Den andra legitima auktoritetstypen hos Weber är traditionell auktoritet, som bygger på att en ledare eller hans familj suttit vid makten så länge någon kan minnas och att därför inga alternativ ens är möjliga att föreställa sig. Den tredje idealtypen är den karismatiska auktoriteten, som grundar sig på en ledares utstrålning och exceptionella kvaliteter. Här pekade Weber främst på utblickar till religiöst ledarskap, men även sekulära ledare kan luta sig mot denna grund. Weber menade också att ingen av de tre legitima auktoritetsformerna kunde förväntas finnas i sin rena form, sin idealtyp, utan att en ledares eller ett ledargarnityrs legitimitet vanligtvis baserade sig på en blandning av de tre (Weber 1983:147). Dock är idealtyperna till analytisk nytta såtillvida att man kan urskilja vilken auktoritetstyp som dominerar under en given tidsperiod och därmed även avgöra hur sårbar en regim är. 
Weber argumenterade för att ett politiskt system som företrädesvis grundar sig på någon annan auktoritetsform än den legala har problem i fråga om hållbarhet över tid. Den legala auktoriteten återspeglar ett kontrakt mellan de styrande och de styrda, där båda parter utgår ifrån rättigheter och skyldigheter inom ramen för ett lands legala och konstitutionella ramverk. Detta ger en långsiktig grund för ömsesidigt förtroende. Den traditionella auktoriteten är sårbar om familjen den vilar på tunnas ut, men har annars en mellanställning i fråga om hållbarhet. Sårbarast är den karismatiska auktoriteten, som Weber beskrev som icke-rationell i den mening att den är främmande för alla regler (Weber 1983: 168). Karismatiskt grundad legitimitet avser inte en fast och given egenskap, den är »inte en binär variabel utan en gradfråga» (jfr Gippert 2016: 524). Den kan gå förlorad då en sittande ledare av någon anledning förlorar sin magi, eller som Weber uttrycker det: "Lydnaden sträcker sig lika långt som tron på hans karisma har sin giltighet» (Weber 1983: 146). Den går inte heller automatiskt i arv då en ledare lämnar över stafettpinnen till en efterträdare. Legitimiteten såsom en relation mellan styrande och styrda måste konstrueras på nytt av efterträdaren till en karismatisk ledare, även om det kan vara så att den nye innehavaren inledningsvis kan dra nytta av sin föregångares popularitet.

Weber förutsåg att legitimitet som främst bygger på karismatisk auktoritet är så flyktig att den måste "rutiniseras» för att kunna bestå. Den kan initiera ett politiskt system men inte garantera dess fortbestånd (Weber 1983: 169; Snyder 2018: 53). Istället måste den karismatiskt grundade legitimiteten omvandlas till någon mera hållbar auktoritetstyp, företrädesvis den legala. Om man begränsar sig till den politiska sfären och exkluderar den spirituellt religiösa, är det tre strategier för rutinisering som kvarstår som relevanta $\mathrm{i}$ Webers indelning av hur en sådan omvandling kan ske. Det handlar om den sittande innehavarens utseende av sin efterträdare, att ledarens stab utser efterträdaren och att denne vinner acceptans eller att den karismatiska auktoriteteten överförs till att vara ärftlig, och genom att någon ny medlem av makthavarens familj utpekas som ledare (Isaacs 2015). I det senare fallet sker då försök till rutinisering till traditionell legitimitet.

Presidentens långvariga popularitet över tid indikerar någon form av personlig legitimitetsgrund, medan den ofta dokumenterade misstron mot statens institutioner signalerar en låg grad av legal auktoritet hos landets politiska system (Sil \& Chen 2004). Legitimiteten i systemet är således i stor utsträckning byggd på den sittande presidentens personliga popularitet, vilket framstår som en bräcklig grund för ett samhällskontrakt motsvarande det som en solid legal auktoritet annars skulle ha tillhandahållit.

Putins legitimitet vilar främst på karismatisk grund. Den bygger på de unika bidrag han sägs ha givit till Rysslands återuppbyggnad och konsolidering efter Sovjetunionens fall, som garant för stormaktsroll, traditionella värden och stabilitet, mera än på hans utstrålning (Sakwa 2008). Det handlar mera om vad han har uträttat och uträttar än någon personlig magnetism (jfr Isaacs 2010). Det handlar istället om kommunikation och om hur framgångsrikt han lyckas förmedla sin berättelse om 
de stora nationella politiska myterna och beskriva sin egen roll i dem för väljarna. Petersson (2017) har argumenterat för att en koppling mellan politisk myt, karismatisk legitimitet och kommunikationsförmåga bidrar till att förklara Putins utbredda popularitet bland väljarna. Med ett tidsmässigt fokus på 2018 års presidentval och dess efterföljd bygger denna artikel vidare på det resonemanget, framför allt när det gäller svårigheterna med omvandling av karismatisk legitimitet i Putins Ryssland.

I Putins legitimeringsgrund finns förvisso också inslag av legal auktoritet eftersom regelbundna val har ägt rum med av konstitutionen föreskrivna intervaller, varvid folket har haft olika kandidater att välja mellan, låt vara att fältet har varit begränsat och kandidaterna inte har fått samma tillgång till utrymme i media och andra resurser. Man skulle också kunna argumentera för att Putins maktinnehav har varat så länge att det börjar få inslag av traditionell legitimitet, eller i vart fall som vissa forskare har benämnt det, "legitimacy by default» (Fish 2001; Gel'man 2010) där legitimitetsgrunden helt enkelt är bristen på tillgängliga alternativ. Igen påminns man om hur fältet av motkandidater såg ut vid presidentvalet i mars 2018 . När presidentens personliga popularitet sviktar eller avtar behövs andra beståndsdelar för att säkra upp systemets fortbestånd (Hutcheson \& Petersson 2016). Putins icke-institutionaliserade karismatiska legitimitet måste därför på sikt rutiniseras för att stabiliteten i systemet ska bestå (Sakwa 2008: 896).

\section{Problemet Medvedev}

I Ryska Federationen finns ingen vice president som temporärt tar över om presidenten dör eller skulle bli oförmögen att fullgöra sina plikter på grund av sjukdom eller annan anledning. Istället är det en funktion som enligt konstitutionens paragraf 92 tillkommer premiärministern. I en sådan situation kan denne ta över som tillförordnad president under högst tre månader, varefter val ska hållas. Här skulle en premiärminister och tillförordnad president förstås få en betydande fördel med sig in en valkampanj. Det var ju också från en sådan "pole position» som Putin på sin tid framgångsrikt tog sig fram till presidentposten år 2000.

Dmitrij Medvedev är Putins premiärminister sedan 2012. Idag besitter han mycket lite av det som skulle kunna benämnas karismatisk legitimitet, och ett rakt skifte från Putin till Medvedev skulle sannolikt inte vara hållbart i legitimitetstermer, om inte någon av de andra typerna av legitimitet kan vidareutvecklas. I maj 2018 blev Medvedev åter nominerad av Putin till att vara premiärminister under presidentens nya, fjärde, mandatperiod. »Herr Medvedev behöver verkligen ingen särskild presentation. Under de senaste sex åren har han lett landets regering» (President of Russia 2018c). Det var med denna lakoniska apostrofering som Putin inför duman introducerade sin kandidat, eller sin »receptionist» för att använda Gel'mans (2015: xiii) elaka men kanske träffande beskrivning. I Putins anförande fanns visserligen ett kollektivt lovordande av regeringens insatser under de gångna åren, men presidenten var anmärkningsvärt återhållsam i fråga om att hylla sin premiärministerkandidat. 
Medvedev har ett tydligt imageproblem. Han hade som nyvald president hösten 2008 en rekordnotering på 83\% gillande, men sedan dess har det gått stadigt utför. Där Putin i augusti 2018 enligt Levada Center hade en notering där $70 \%$ gillade och $30 \%$ ogillade honom hade Medvedev det väsentligt motigare med $28 \%$ som gillar och $71 \%$ som ogillar. Sedda över tid illustrerar Putins och Medvedevs popularitetskurvor tydligt kontrasterna de båda ledarna emellan. Putins gillanoteringar har konsekvent legat på en hög nivå sedan år 1999, aldrig sjunkit lägre än till $61 \%$ och alltid haft en rejäl övervikt över antalet ogilla-noteringar. Från och med början av 2014 och annekteringen av Krim vände hans opinionssiffror uppåt och låg under en lång period stabilt på 80\% eller däröver (Levada-Center 2018).

Givet opinionsraset för hans högra hand ter det sig lite förvånande att den annars trendkänslige presidenten givit Medvedev förnyat förtroende som premiärminister. Till synes paradoxalt kan dock Medvedev genom sin svaga image faktiskt ha bidragit till att bygga upp och konsolidera presidentens varumärke. Den relativt veke Medvedev har framhävt Putins styrka. Där den senare har ägnat sig åt en maskulin kraftsport som judo har Medvedev förespråkat badminton. Där Putin har stått som en garant för Rysslands allt starkare ställning i världen och stabilitet och ordning på hemmaplan har Medvedev inte lyckats förmedla det intrycket. Putin, som den moderne efterföljaren till gamla tiders tsarer, har därigenom kunnat bibehålla sin image av stark kraft, att vara en handlingens man som kan få saker och ting uträttade om han bara är informerad om sakernas tillstånd (Mamonova 2016).

Att ha en regeringschef som kan tjänstgöra som "fall guy» i en kris kan därtill vara en tillgång. Presidenten kan göra ett bondeoffer, gå vidare och fortsätta att framstå som alla goda gåvors givare och därmed bibehålla sin legitimitet. Putin har tidigare visat sig inte vara främmande för ett liknande tillvägagångssätt. I samband med en brandkatastrof $i$ ett köp- och aktivitetscentrum i den sibiriska staden Kemerovo våren 2018 omkom ett 60-tal människor varav ett stort antal barn. Ett omfattande fusk mot säkerhetsföreskrifterna uppdagades. Samtidigt kunde Putin genom ett besök på plats, där han visade att han delade medborgarnas upprördhet på alla punkter, manifestera att han kunde och skulle få saker gjorda (President of Russia 2018a). Det budskap som han tycktes vilja förmedla var att om bara han hade känt till detaljerna skulle katastrofen aldrig ha ägt rum. Mycket snart därefter fick den mångårige guvernören i regionen, Aman Tuleev, avsked på grått papper. Den traditionella alliansen mellan tsaren och folket aktualiserades med moderna förtecken.

\section{Han som inte får nämnas - Problemet Navalnyj}

I samband med den kritik som Putin och hans administration under sommaren 2018 ådrog sig för de planerade försämringarna i pensionsvillkoren för ryska män och kvinnor började Putins popularitetskurva åter peka nedåt. I början av hösten 2018 låg den strax under 70-procentsnivån (Levada-Center 2018). Möjligen förebådas en ny kris för regimen, och kanske uppvisar presidentens karismatiska legitimitet 
nu tecken på slitage. Den person som ligger närmast att kunna utmana Putin i termer av karismatisk legitimitet är oppositionsledaren och antikorruptionsaktivisten Alexej Navalnyj (född 1976). Denne har metodiskt byggt upp sin politiska plattform och har, i kraft av sin relativt unga ålder och sin förtrogenhet med sociala medier ett tilltal och en trovärdighet hos den yngre generationen som Putin saknar (MoenLarsen 2014). Han har, mycket beroende på detta, kommit att framstå som det främsta hotet mot "Kremls status quo» (Lassila 2016: 119).

När Navalnyj med kort varsel ställde upp i borgmästarvalen i Moskva år 2013 fick han visserligen se sig besegrad av den sittande borgmästarkandidaten Sergej Sobjanin, men fick ändå mer än en fjärdedel av rösterna. Han har via slagkraftig retorik och paroller såsom "tjuvarnas och bedragarnas parti» om Putins stödparti Förenade Ryssland, „Rösta på vem som helst utom Förenade Ryssland!» och »Inte vår tsar!» om Putin, visat sig kunna få genomslag i opinionen, inte minst genom sitt effektiva bruk av sociala medier.

Våren 2017 lyckades Navalnyj med sina sarkastiska giftpilar skada Medvedevs trovärdighet svårt. I en uppmärksammad video på Youtube som i september 2018 hade mer än 27,7 miljoner visningar (YouTube 2017) hävdade han bland annat att premiärministern förskingrat allmänna medel och för ett hundratal miljoner US-dollar byggt en storslagen semesteranläggning, komplett med ett renoverat kulturhistoriskt palats, hotell, pooler, skidbacke och även ett litet hus för egendomens ankor. Den senare detaljen gjorde på kort tid den gula gummiankan till en kraftfull symbol för makthavarnas, särskilt Medvedevs, korruption (The Times 2017). Semesteranläggningens sammanlagda areal uppgick till 80000 kvadratmeter, vilket motsvarade 30 stycken Röda Torget eller 114 fotbollsplaner, och i videon jämfördes detta med de betydligt mera anspråkslösa semesterboenden som Tysklands förbundskansler Angela Merkel respektive USA:s expresident Bill Clinton förfogar över.

Navalnyjs salva visste var den tog, och är säkert en bidragande orsak till Medvedevs dåliga opinionssiffror. Sannolikt räds Putin och hans närmaste krets vad välriktad kritik från Navalnyj skulle kunna innebära även för presidentens image. Samtidigt skulle man kunna tolka Putins delvis överraskande beslut att ge Medvedev fortsatt förtroende som regeringschef som ett led i någon slags kraftmätning med Navalnyj. Om han hade låtit Medvedev lämna sin post skulle det kunna ha lästs som att ge vika för den ledande kritiker som regimen annars konsekvent har valt att förminska.

Ett genomgående drag från Putinadministrationens sida har varit att föra fram anklagelser om ekonomiska oegentligheter mot Navalnyj, vilket fått den högljudde kritikern att framstå som någon som kastar sten i glashus (Weiss 2013). Redan under 2013 kommenterade Putin med hänsyftning på sin kontrahent att de människor som är ivrigast att ropa "stoppa tjuven!» vanligtvis är de som har stulit saker själva (President of Russia 2013b). Uttalandet hade en klar adress. En villkorlig dom från året innan för ekonomiska brott användes av myndigheterna som förevändning för att inte tillåta Navalnyj att ställa upp i presidentvalet 2018. 
Flera gånger inför valet 2018 fick Putin i offentliga sammanhang frågan om varför Navalnyj inte tilläts ställa upp som presidentkandidat. Han undvek varje gång att nämna sin antagonist vid namn, och använde sig istället av beteckningar som "figuren som du nämnde» eller "personen som du refererade till». Som retorisk strategi kan detta kanske vara framgångsrikt för att förminska opponenten, men samtidigt kan tankarna ledas till ett voldemortskt »han-som-inte-får-nämnas-vid-namn». I vilken grad myndigheternas kampanj mot Navalnyj har varit en avgörande faktor är svårt att säga, men uppenbarligen har hans image fått hårda törnar i opinionen under senare år. I april 2011 var det enligt Levada Center 33\% av de tillfrågade som menade att de skulle kunna tänka sig att rösta på honom i ett presidentval, men i februari 2017 hade siffran sjunkit till 10\%, samtidigt som de som var kategoriskt emot honom hade ökat från 19 till 63\% under samma tidsperiod (Levada-Center 2017).

\section{Tidigare års hantering av efterträdarfrågan}

Således finns det bland de av regimen erkända aktörerna inte någon identifierad trovärdig efterträdarkandidat, medan den person som i termer av potentiell karismatisk legitimitet skulle kunna utmana Putin behandlas som onämnbar och icke existerande. Frågan om rutinisering av den karismatiskt grundade legitimitet som finns i systemet uppkommer därvid åter. Putins återkommande hänvisningar till att det är folkets sak att rösta fram en ny ledare när den dagen kommer, och att han själv önskar att rätta sig efter konstitutionens bokstav antyder att han också vill hålla kvar vid det legala inslaget som partiell legitimitetsgrund. Samtidigt tyder inte den förda politiken på att den parlamentariska maktens inflytande skulle öka framöver, så någon rutinisering av karisma via den strategin tycks inte vara att vänta. Inte heller har han lyft fram någon av sina döttrar eller någon annan släkting i försök att bygga traditionell legitimitet som alternativ.

Det återstår alltså att försöka överföra karismatisk legitimitet till en efterträdare. En blick bakåt på den nära historien, till 1999 och 2007/2008, visar att handplockningsstrategin har varit den metod att försöka rutinisera karisma som har föredragits av sittande ryska presidenter.

Första gången som ett presidentskifte var aktuellt efter Sovjetunionens fall var år 1999 då en alltmera skröplig Boris Jeltsin behövde lämna ifrån sig makten, såväl av konstitutionella skäl, eftersom han redan hade suttit under två mandatperioder, som av uppenbara hälsoskäl. Jeltsin hade en gång åtnjutit karismatisk legitimitet, men under hans andra mandatperiod fanns inte mycket kvar av den varan (Shevtsova 1999). Dock var han Ryska Federationens förste president, och det legala argumentet utgjorde hans främsta legitimitetsgrund. Hans direkta utkorande av en efterträdare, Putin, blev den successionsstrategi som valdes.

Putin var den man som systemet frambragt som ledarkandidat. I omvärlden var han praktiskt taget okänd utanför Rysslandskännarnas krets. Putins initiala tillgång var att han var godtagbar i alla större politiska läger. Såväl nationalister som 
sovjetnostalgiker och liberaler kunde hitta något tilltalande hos honom, och han hade stark uppbackning av kraftministerierna (Chen 2016). Troligtvis skulle systemet kunna identifiera en kandidat med liknande profil ännu en gång, och det förefaller alltjämt vara det mest näraliggande scenariot för Putins fjärde mandatperiod.

I samband med det andra presidentskiftet, 2008, verkade det länge som om två etablissemangsfavoriter, dåvarande vice premiärministern Medvedev och förre försvarsministern Sergej Ivanov, skulle ställas mot varandra. Om två till synes jämnstarka kandidater skulle ha ställt upp i valet, skulle segraren ha kunnat påräkna betydande legal auktoritet (Hanson 2011). Dock blev det inte så. Putins stödparti Förenade Ryssland nominerade i december 2007 Medvedev till sin kandidat på Ivanovs bekostnad. Putin uttalade snabbt sitt stöd, och Medvedev återgäldade omgående detta genom att nominera honom till sin premiärministerkandidat. Om detta var ett försök att rutinisera Putins karisma och överföra den till efterträdaren så var förfarandet inte särskilt framgångsrikt. Medvedev lyckades som nämnts inte bibehålla magin. Arrangemanget gjorde det emellertid möjligt för Putin att i realiteten behålla sin makt från sin nygamla position som premiärminister. Dessutom, och allra mest väsentligt, öppnade det vägen för honom att återkomma som president en tredje och en fjärde gång, då konstitutionen ju inte medger någon innehavare att bekläda ämbetet mer än två mandatperioder i följd.

Den fiffiga överenskommelsen mellan Putin och Medvedev var dock grundligt impopulär. Även om Putin ändå blev vald med solid majoritet i presidentvalet 2012 återhämtade sig inte hans popularitetssiffror förrän under 2014, efter de Olympiska vinterspelen i Sotji och, framför allt, annekteringen av Krim. Efter dessa händelser sköt presidentens popularitetskurva i höjden och passerade 80-procentstrecket. Där har den i stort sett legat stabilt fram till sommaren 2018 och nedgången i pensionsdiskussionernas spår (Levada-Center 2018). Samtidigt är det inte obefogat att hävda att det faktiskt var 2012, vid Putins återkomst till presidentämbetet, som Rysslands successionskris inleddes (Snyder 2018: 50). Den har tagit tid på sig att mogna och är ännu inte akut, men dagen kommer allt närmare när den blir det.

\section{Uppskjuten succession?}

Under Putins fjärde mandatperiod finns förstås fortfarande alternativet att identifiera en efterträdare som inte reellt blir ledare, utan en galjonsfigur, en Medvedev 2.0, som låter den nu sittande presidenten ha det avgörande politiska inflytandet även efter det att han formellt avgått från presidentposten. Dock ska man komma ihåg att så länge som Ryssland har kvar särdraget att vara elektoralt auktoritärt och regelbundna och till formen korrekta val fortsätter att utgöra en legitimeringsgrund för regimen, finns det trots allt en möjlighet att folket faktiskt underlåter att rösta fram den handplockade kandidaten, stödet från statskontrollerade media och statsorgan till trots (Kendall-Taylor \& Franz 2018). Om opinionen uppfattar det som att det pågår ett nytt trixande med konstitutionens anda liksom var fallet 2011-2012, lär 
protester följa. Det får nämligen uppfattas som föga troligt att väljarna skulle kunna duperas och låta sig nöja med en Medvedev 2.0 - framför allt om det just vore den nu tjänstgörande premiärministern som än en gång skulle kallas in under fanorna. En sådan strategi skulle därför vara förknippat med ett stort risktagande från regimens sida.

Med den kvalificerade majoritet som Förenade Ryssland förfogar över i parlamentet vore det i sig inte några problem att ändra konstitutionen. Den skulle kunna ändras på flera sätt, till exempel genom att ytterligare förlänga mandatperioden från nuvarande sex år eller genom att avskaffa den begränsning som säger att ingen president får inneha ämbetet under mer än två mandatperioder i följd (Kendall-Taylor \& Franz 2018). Redan inför presidentvalet 2008, innan Medvedev fördes fram som det ryska maktetablissemangets kandidat, försiggick en intern diskussion om inte en lösning där konstitutionen ändrades till förmån för den då sittande presidenten Putin vore att föredra (Hanson 2011). En provision där presidenten skulle kunna sitta på livstid enligt centralasiatisk modell vore teoretiskt fullt möjlig. Det senare alternativet har exempelvis använts av Putins kinesiske presidentkollega Xi Jinping. Samtidigt har forskare påpekat att det tidigare relativt ansiktslösa ledarskapet i Kina efter Deng Xiaoping har bidragit till den politiska stabiliteten i landet, medan ett personligt förknippat ledarskap i ett land där successionsreglerna inte är fullständigt klara kan verka i motsatt riktning om populariteten avtar (Chen 2016). Detta är en problematik som även den politiska ledningen i Ryssland har att fundera över (Dukalskis 2017).

\section{Slutord}

Valet av Putin till Rysslands president i mars 2018 hade föga nyhetsvärde. Valutgången var den av alla förväntade, och de enda spänningsmomenten var egentligen hur högt Putins röstetal skulle hamna, vem som skulle komma tvåa och med vilken andel av rösterna, samt hur högt det officiella valdeltagandet skulle bli. Putins överraskningsfria valseger konsoliderade intrycket av att Ryssland befinner sig inne i en period som är så stabil att den i politiskt hänseende kan benämnas en ny stagnationstid.

Max Weber förutsåg att karismatisk auktoritet som ligger till grund för en stats legitimitet måste omvandlas för att inte vara av tillfällig karaktär och således kunna bestå efter att den karismatiske ledaren har gjort sorti. I Ryssland aktualiseras efterträdarfrågan obevekligt allt eftersom tiden går. Ett sätt att skjuta upp den något vore att få parlamentet att lyfta begränsningen att ingen president får sitta mer än två mandatperioder i följd. Det tycks dock mindre troligt. Den avhållande effekten från förväntade massprotester inifrån, liksom förmodad kritik från omvärlden, ska inte underskattas, men här ska kanske också sökas motiv hos presidenten själv. Putin har således flera gånger avfärdat möjligheten att sätta sig över 1993 års konstitution. Inför presidentvalet 2018 underströk han att han aldrig hade brutit mot 
konstitutionen och aldrig hade ändrat den (det var under Medvedevs presidenttid som förändringen av mandatperiodens längd från fyra till sex år initierades), och att han inte hade för avsikt att göra det nu heller. Denna princip tycks vara en stark drivkraft hos Putin (President of Russia 2018b) som gärna framhåller att presidenten är konstitutionens garant (President of Russia 2013a). Han tycks se detta som centralt i sin legitimeringsgrund, och verkar helt enkelt inte vilja ha som sitt eftermäle att ha trixat med konstitutionens bokstav. Däremot föreföll inte flexibiliteten i fråga om att tolka dess anda ha ingivit honom några betänkligheter inför valen 2011-2012. Frågan är då om något liknande kan tänkas uppkomma mot slutet av den sexåriga mandatperiod som inleddes våren 2018.

Om stiltjen består när det gäller potentiella kandidater att efterträda Putin kan detta vara ett tecken på att oroliga tider stundar. Den välkända sociologen Olga Kryshtanovskaya har framhållit att stabiliteten kan vara bedräglig, eftersom det i rysk historia traditionellt har varit så att långa perioder av maktinnehav av en och samma ledare avlösts av perioder med oro, oreda och instabilitet (Whitehouse 2018). Med historikern Yuri Slezkine kan man dessutom konstatera att det i rysk politisk historia egentligen aldrig funnits några regler för en ordnad succession (Petersson 2017). Putin och hans omgivning måste förr eller senare ta sig an denna problematik. Den sittande presidentens karismatiska auktoritet måste bindas in och omvandlas till en mera systembunden legitimitet. Att Putin klart och tydligt utpekar en efterträdare vore en väg att gå, även om det $\mathrm{i}$ nuläget är svårt att urskilja någon av systemet uppburen och samtidigt trovärdig kandidat till att ta över. Ett annat sätt vore att via konstitutionella omdispositioner förlänga betänketiden och skjuta upp problemen ytterligare något år, men till sist och slutligen måste frågan ändå hanteras.

\section{Referenser}

Bacon, Edwin (2017) Inside Russian Politics. London: Biteback.

Bueno de Mesquita, Bruce \& Alastair Smith (2017) "Political Succession: A Model of Coups, Revolution, Purges, and Everyday Politics». Fournal of Conflict Resolution 61 (4): 707-743.

Central Election Commission of the Russian Federation (2018) "Results of Russian Presidential Elections 2018». Tillgänglig på http://www.cikrf.ru/eng/information-center/results-of-russian-presidential-elections-2018. php. Läst 21 september 2018.

Chen, Cheng (2016) The Return of Ideology: The Search for Regime Identities in Postcommunist Russia and China. Ann Arbor: University of Michigan Press.

Dukalskis, Alexander (2017) The Authoritarian Public Sphere. Legitimation and Autocratic Power in North Korea, Burma, and China. London and New York: Routledge.

Fish, M. Steven (2001) "When More is Less: Superexecutive Power and Political Underdevelopment in Russia", iVictoria E. Bonnell \& George W. Breslauer (red.) Russia in the New Century: Stability or Disorder? Boulder: Westview Press (15-34).

Gel'man, Vladimir (2010) »Regime Changes Despite Legitimacy Crises: Exit, Voice, and Loyalty in PostCommunist Russia». Fournal of Eurasian Studies 1 (1): 54-63.

Gel'man, Vladimir (2015) Authoritarian Russia: Analyzing Post-Soviet Regime Changes. Pittsburgh: University of Pittsburgh Press.

Gippert, Birte J. (2016) «The Sum of Its Parts? Sources of Local Legitimacy». Cooperation and Conflict 51 (4): 522-538.

Hanson, Stephen E. (2011) "Plebiscitarian Patrimonialism in Putin's Russia: Legitimating Authoritarianism in a Postideological Era». The Annals of the American Academy 636: 32-48. 


\section{4 | BO PETERSSON}

Hutcheson, Derek S. \& Bo Petersson (2016) "Shortcut to Legitimacy: Popularity in Putin's Russia». EuropeAsia Studies 68 (7): 1107-26.

Isaacs, Rico (2010) "'Papa'- Nursultan Nazarbayev and the Discourse of Charismatic Leadership and NationBuilding in Post-Soviet Kazakhstan». Studies in Ethnicity and Nationalism 10 (3): 435-452.

Isaacs, Rico (2015) „Charismatic Routinization and Problems of Post-Charisma Succession in Kazakhstan, Turkmenistan and Uzbekistan". Studies of Transition States and Societies 7 (1): 58-76.

Kailitz, Steffen \& Daniel Stockemer (2017) "Regime Legitimation, Elite Cohesion and the Durability of Autocratic Regime Types». International Political Science Review 38 (3): 332-348.

Kendall-Taylor, Andrea \& Erica Frantz (2018) "Putin's Succession Conundrum: How Authoritarians Navigate the Challenge». Foreign Affairs, 21 mars. Tillgänglig på https://www.foreignaffairs.com/articles/russianfederation/2018-03-21/putins-succession-conundrum. Läst 2 maj 2018.

Konrad, Kai A. \& Vai-Lam Mui (2016) "The Prince—or Better No Prince? The Strategic Value of Appointing a Successor». Fournal of Conflict Resolution 61 (10): 2158-2182.

Lassila, Jussi (2016) »Aleksei Naval'nyi and Populist Re-ordering of Putin's Stability». Europe-Asia Studies 68 (1): 118-137. DOI: 10.1080/09668136.2015.1120276.

Levada-Center (2017) „Press-Releases: Aleksey Navalny», 20 mars. Tillgänglig på https://www.levada.ru/ en/2017/03/20/aleksey-navalny/. Läst 7 maj 2018.

Levada-Center (2018) "Indicators». Tillgänglig på http://www.levada.ru/en/ratings/. Läst 3 september 2018.

Mamonova, Natalia (2016) "Naïve Monarchism and Rural Resistance in Contemporary Russia». Rural Sociology 81 (3): 316-342.

Moen-Larsen, Natalia (2014) "Normal nationalism': Alexei Navalny, LiveJournaland 'the Other'». East European Politics 30 (4): 548-567. DOI: 10.1080/21599165.2014.959662.

Netelenbos, Benno (2016) Political Legitimacy beyond Weber. London: Palgrave Macmillan.

Petersson, Bo (2017) „Putin and the Russian Mythscape: Dilemmas of Charismatic Legitimacy». Demokratizatsiya: The fournal of Post-Soviet Democratization. 25 (3): 235-254.

President of Russia (2013a) "Direct Line with Vladimir Putin», 25 april. Tillgänglig på http://en.kremlin.ru/ events/president/news/17976. Läst 2 maj 2018.

President of Russia (2013b) "News Conference ofVladimir Putin», 19 desember. Tillgänglig på http://en.kremlin. $\mathrm{ru} /$ events/president/news/19859. Läst 17 maj 2018.

President of Russia (2016) "Meeting of the Valdai International Discussion Club», 27 oktober. Tillgänglig på http://en.kremlin.ru/events/president/news/53151. Läst 9 maj 2018.

President of Russia (2018a) "Meeting with Local Activists in Kemerovo", 27 mars. Tillgänglig på http:// en.kremlin.ru/events/president/news/57139. Läst 3 april 2018.

President of Russia (2018b) „Interview to American TV channel NBC», 10 mars. Tillgänglig på http:// en.kremlin.ru/events/president/news/57027. Läst 25 april 2018.

President of Russia (2018c) "The President Took Part in a State Duma Plenary Session», 8 mai 2018. Tillgänglig på http://en.kremlin.ru/events/president/news/57431. Läst 9 maj 2018.

Sakwa, Richard (2008) "Putin's Leadership: Character and Consequences». Europe-Asia Studies 60 (6): $879-897$.

Shevtsova, Lilia (1999) Yeltsin's Russia: Myths and Reality. Washington DC: Carnegie Endowment for International Peace.

Sil, Rudra \& Chen Cheng (2004) "State Legitimacy and the (In)significance of Democracy in Post-Communist Russia». Europe-Asia Studies 56 (3): 347-368.

Snyder, Timothy (2018) The Road to Unfreedom: Russia, Europe, America. New York: Tim Duggan Books.

The Times (2017) "US Plots to 'Overthrow Putin with a Rubber Duck'», 28 september. Tillgänglig på https:// www.thetimes.co.uk/article/us-plots-to-overthrow-putin-with-a-rubber-duck-starting-in-city-of-izhevskalexei-navalny-8sh8zkf87. Läst 21 september 2018.

Weber, Max (1983) Ekonomi och Samhälle 1 Förståendesociologins grunder. Sociologiska begrepp och definitioner. Ekonomi, samhällsordning och grupper. Lund: Argos.

Weiss, Michael (2013) "Rights in Russia: Navalny and the Opposition». World Affairs 176 (4): 72-80.

Whitehouse, Mark (2018) "What Comes After Putin Could Be Trouble. The transfer of power will be perilous, says a prominent Russian sociologist”". Bloomberg Opinion, 25 augusti, https://www.bloomberg.com/ view/articles/2018-08-25/putin-s-succession-plan-could-be-trouble-for-russia. Läst 6 oktober 2018.

YouTube (2017) "Don't Call Him 'Dimon'», 2 mars. Tillgänglig på https://www.youtube.com/watch?reload=9 $\& v=$ qrwlk7_GF9g\&t=441s. Läst 21 september 2018 . 